\title{
Is Natural Resource a Blessing or a Curse to Humanity? Confusion in Mau Forest Complex Utilization in Kenya
}

\author{
George Ouma Ochola* \\ Rongo University, Department of Agronomy and Environmental Studies, Rongo, Kenya
}

Submission: August 13, 2018; Published: August 27, 2018

*Corresponding author: George Ouma Ochola, Department of Agronomy and Environmental Studies, P.O. Box 103-40404, Rongo, Kenya, Email: jochola2012@gmail.com

Abstract

The use of natural resources has raised a global debate on whether they are really a blessing or curse to the people. The role natural resources play in supporting human cannot be over-emphasized. Land, forests, water, minerals, wildlife, wetlands among others significantly contribute to the survival of man. Land is a factor of production as it supports agricultural activities upon which man depends. It provides room for settlement and support various human activities like pottery, brick making recreational activities among others. Forest resources have numerous benefits to man. Air purification or provision of ground for waste assimilation is one of the most important functions of forests. They are habitat to other forms of wildlife and also contribute in completion of water cycle. It is clear to everyone that there can be no life without water. A part from the fact that it supports aquatic life, a bigger percentage of human body fluid is made of water. Other life forms on land also depend on it. Minerals are sources of income to human. The use of these resources has sparked debate as it becomes difficult to use them without depletion and degradation. Their use is also associated with conflicts that at times lead to loss of lives. The study was informed from such arguments.

Keywords: Natural Resources; Blessing; Curse; Mau Forest; Kenya

\section{Introduction}

Globally, there has been a confusion on who owns the natural resources found in our countries. This question has been left unanswered for centuries and people have taken advantage of this lack of knowledge and have treated the natural resources as if they own them. There has been struggle for example in defining our boundaries when it comes to land utilization. The question I may ask if that "Who owns the land or does anybody own land?" An attempt to answer this question will enable us understand and treat the natural resources with the honour they deserve. Human being have killed one another while fighting over land as a resource. As has been mentioned, land holds a lot of significance to man. Our agricultural activities take place on land, we build our shelter on, move on land, our communication systems are supported by land, we get building materials from land together with a number of activities that this paper might not exhaust. The question is who owns land. Having appreciated land as a natural resource and a factor of production, it becomes imperative to know, recognize and appreciate that it land that owns us. We found it when we came to earth, we make use of it to generate food and other products that support us while still alive. What we have to remember as human beings that we finally die and get back to earth as the Bible puts it in the book of Genesis if I may quote. Once dead, are recycled to generate nutrients that is again utilized by plants to support other human being.

\section{Discussion}

The acquisition and use of land as a resource has brought issues among neighbours, communities and even between the locals and the government. This has been evidenced in Mau Forest Complex where the locals are proving ownership of land by showing their title deeds which they acquired when they bought land right inside Mau forest. The only thing they need to know and understand first is that it is land that owns individuals before they are exposed to real benefits of the forest not only to them but to the Kenyan community and the other communities outside Kenya. The feeling and misconception that human own land as a resource has made them utilize it as if they truly own it. They cut trees the way they like, clear other forms of vegetation, use poor methods in their agricultural activities for their personal gain. Seemingly, the people who settled in the Mau forest have felt the pinch of degrading the forest because may be they have not witnessed the direct impact on themselves. To some scholars who might have known the value that forest ecosystem holds mentioned them to include: air purification, creation of micro-climate, habitat to other micro-organisms, 
support of recreational activities, catchment area for rivers and other bodies of water, source herbs/medicine, protection of soil from erosion, addition of aesthetic value, source of raw materials for milling industries, source of fuel, waste assimilation and acting as carbon sinks among other significance that this paper might have not mentioned.

It clear that man has man is not focused on the ecological roles performed by the forest ecosystems but are only looking at the forest and are focusing fuel and building materials as was noted by Bewernick [1]. The other roles performed by the forest are either hidden to them or they have intentionally closed their eyes and turned their ears deaf and do not want to get anything concerning these other significance. Consequently, these significance are compromised by man activities such as illegal logging, agricultural activities, settlement and charcoal burning. The current eviction in Mau Forest Complex has not been perceived positively by the forest inhabitants. Ironically, well-educated politicians who might have undergone proper exposure on the importance of forest have also joined as closed their eyes in the name of vote securing. It should be very clear to everyone whether young or adult that our future depend barely on natural resources thus how we utilize them directly affect our future well-being.

Mau Forest Complex ecosystem hold diverse significance not only to energy sector through supporting rivers like Sondu to generate Hydro-electric power but also to agricultural, tourism, fisheries and industrial sectors. It worth noting by every Kenyan that Mau Forest Complex is a catchment and source of many rivers such as Molo, Njoro, Nyando, Yala, Naishi, Mara, Makalia, Ewaso Nyiro, Nderit among others. Among these rivers, some end up in Lake Nakuru, lake Elementaita, Lake Bogoria, Lake Victoria which support various aquatic ecosystems which are equally significant as was contended [2]. In general, the water help by these river and lakes support various human activities not only at the catchment but also down-stream. The water is used direct for domestic purposes such as drinking, washing, bathing, cooking among others. It known that all living organisms cannot survive without water. The man that contributes immensely in the destruction this forest and does not want to hear anything concerning its conservation not only utilizes its water but also enjoys the purified air that has been made available by the forest. Some scholar having seen the significance of water described it as 'life' and contend that anything that disrupt its supply and distribution, disrupts the very survival of humanity. Water is not only used by man but also other wildlife in the forest areas like the wild-beasts, lions, crocodiles, hippos among others which the country relies on in boosting its tourism sector and collects her revenue from through foreign exchange. It is unfortunate and with a lot of sadness to acknowledge and recognize the low levels of water in the rivers supported by the Mau Forest Complex. The aquatic organisms supported by these rivers and are becoming endangered. The fish species are being exposed and this increases chances of being seen by the predators as well as man who do not spare them. Other species equally are being endangered because of their exposure and lack of adequate water in these rivers and lakes. The hippos sometimes find refuge in water together with crocodiles. The receding water levels endangers them. The rivers supported by this water tower have been seen to contribute to generation of electric power such as Sondu River where Odino Falls is established. The declining water levels affect power generation and consequently lead to power rationing that negatively affect the income generating activities. There are a number of industrial activities supported by these rivers which are affect due to the change of water flows as a result of degradation of Mau forest caused by its inhabitants.

As has been mentioned, water is very significant not only to man but also to other forms of life. Aquatic biodiversity have supported many and there existence is crucial for ecological balance. Is worth noting that even the flamingo population is affected due to the receding water levels of the four rivers from Mau forest feeding Lake Nakuru. These at times forces them to migrate and will consequently affect the Kenyan tourism sector. The only challenge it that human have become very selfish and does not want to consider and give value these resources that support his life. This comes due lack of understanding that without these resources like water and forest on earth, man cannot survive. He has totally decided to close his eyed and will only open it when he is dehydration because of lack of clean water and suffocating because of polluted air. It is imperative to start appreciating what nature provides. The Biblical explanation in the story of creation by God in the book of Genesis gives us the order of creation where man comes last. In my view that stands to be criticized, God probably made everything that could support man's life before bringing him into life so as not to lack. Land, water and vegetation came first before man to provide a place to stay, water to quench thirst and make the body function and vegetation to purify the air and be source of human's food for better life. It is because of man's failure to recognize and appreciate these resources as life forms that enable them live on earth. Instead, man thinks that he owns these resources and has failed to appreciate them. He clears, vegetation, degrades land, pollutes water and when reminded by the scholars who might have perceived this as act of committing suicide and killing future, they are ready to fight because of lack of knowledge or exposure. This brings me to acknowledge and recognize the value of education that expose one to environmental issues.

This study has noted that greed, selfness or individualism together with lack of knowledge/exposure on who owns another. Is it we (man) or the environment/natural resources? From these study Mau Forest Complex has been degraded.

\section{Illegal Logging}

Massive logging has been witnessed in the forest where sections of the forest have been left bare with only stumps of cut trees that signify that they were initially covered with vegetation as was noted [3]. The act of logging has been driven by self and 
lack of understanding of the importance held by the forest. People encroach the forest and start the business of timber as indicated in Figure 1 that shows a packed saw mill which indicates that there is high level of logging in Mau forest.

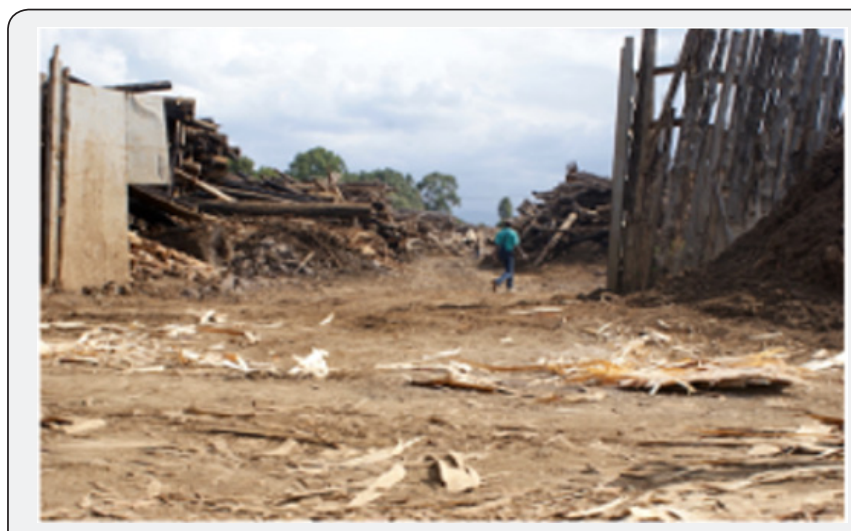

Figure 1: A packed saw mill in Mau forest.

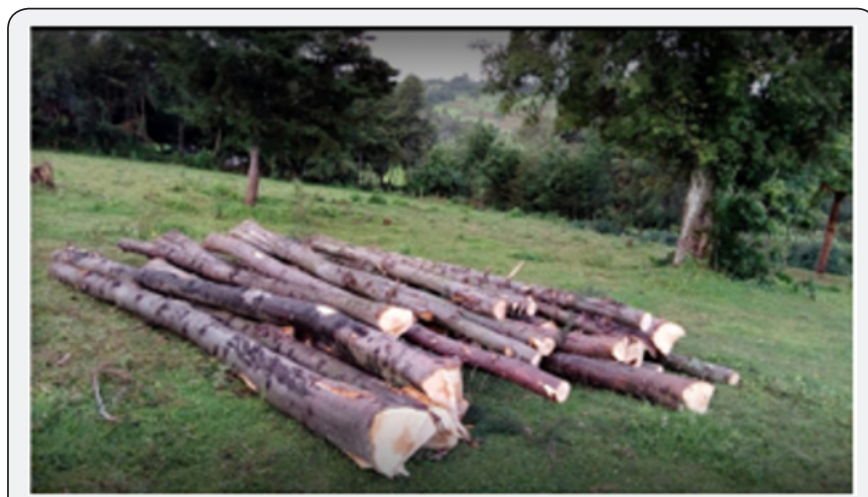

Figure 2: Logs awaiting transportation.

Environmental management advocates for intra and intergenerational equity. The use of this forest even if some of the communities were granted access of the forest to inhabitate have not taken this into practice. Instead, they use the forest resources as there is no tomorrow and none of them would want to listen. The only claim they hold is that they rightfully own the land in the forest. What remain unclear to them is that an individual's impact might grow cumulatively to become a global impact. Mau forest not only support Kenya but the other resources it support like Lake Victoria which has a connection with River Nile is a trans-boundary resource as was asserted [4]. This paper calls for integration of the two principles mentioned under this sections to be upheld. The impact of illegal logging is real on Mau forest and this compromises the forest ability to perform its ecological roles. The rate of evapo-transpiration is lowered as a number of trees are felled to produce timber for sale and at the same time provide logs used for various activities. All these are done to meet self-interest that is not concerned with the lives of the future generation. Thus unsustainable development. We need forest timber today, tomorrow and in the future. The Figures 1 $\& 2$ does not indicate the exhaustion in terms of portraying how the forest suffer illegal logging. More can still be found under the web-site provided as the source. The act illegal logging has direct impact on land as it leaves the land bare and makes it susceptible to agents of erosion. This degrades land as the top soil is swept away by the run off.

\section{Charcoal Burning}

This paper noted earlier that man has been focusing on forest and what he perceives first is fuel either in form of wood fuel or firewood. The low class social status of the Kenyan individuals leaves them with very limited options that includes relying basically on wood-fuel as the source energy used at home. Mau forest Complex suffers significantly as a result of this. Trees are felled and some of them used to burn charcoal that not only benefit the rural community but also the urban dwellers such as Narok, Bomet, Kericho, Nakuru, Mulot, Longisa among others. The use of charcoal has not been left to the low class individuals alone but even the middle and the upper classes. Just like car wash, the person washing the car inside a water body might be ignorant of the impact it causes the water but the owner of the car who might be very educated and learned decides to closed his eyes and feel unconcerned with oils that will be left on water that will degrade water quality and suffocates aquatic organism. The case applies with the use of charcoal. You buy it and use frequently but no one asks about the negative impacts at the source of this charcoal. It means that even the learned contribute to environmental degradation. Since they support use of charcoal and car wash inside the water bodies.

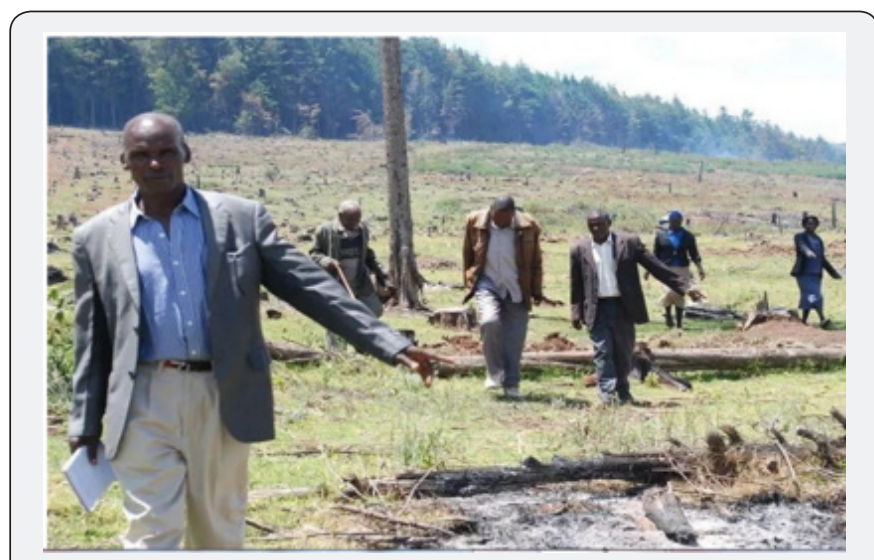

Figure 3: Section of the forest cleared for charcoal.

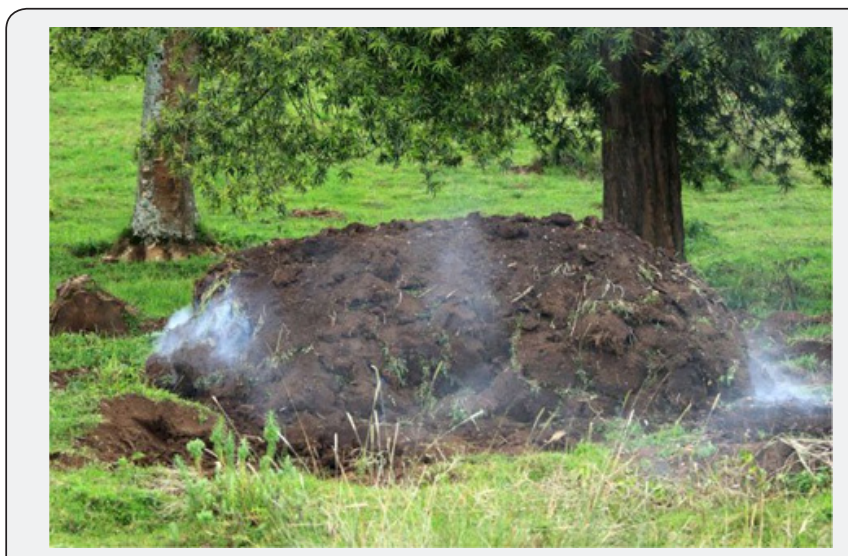

Figure 4: Charcoal Kiln in Mau Forest. 
Mau Forest Complex suffers immensely due charcoal burning. Other scholars such as Zungu noted that man must live no matter how hard he puts food on the table. Figures $3 \&$ 4 shows how people have encroached the forest and practice charcoal burning.

The impacts caused by charcoal burning are more or less related to the ones of illegal logging as the process of charcoal burning starts with felling of trees. This paper has established that some of the occupants/inhabitants of Mau forest Complex may be considered to be living below the poverty line and therefore left with no alternative other than exploiting the tree resource that they perceive to abundant and is within their reach. Their level of poverty in this case cannot be proriotised at the expense of the role performed by the trees thy fell for charcoal burning. It would be very nice if it dawns on the people of Kenya that no individual can pay the price of a single tree considering its role of air purification. If only they could know that many lives have been lost because they cannot afford the Intensive Care Unit price where oxygen is paid for per minute while the vegetation makes it freely available for man. It is true that man struggles to live like the ones shown in Figures 5 \& 6 but what nature provides us with should not be slighted.

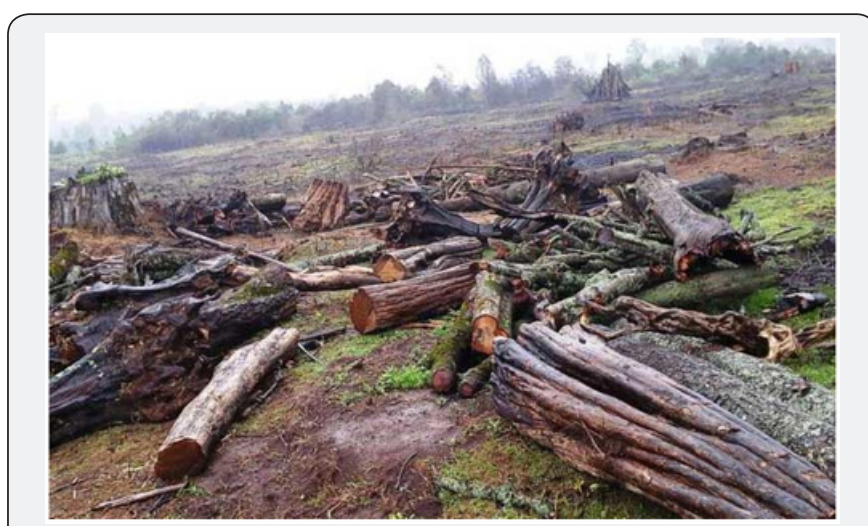

Figure 5: Log for charcoal burning.

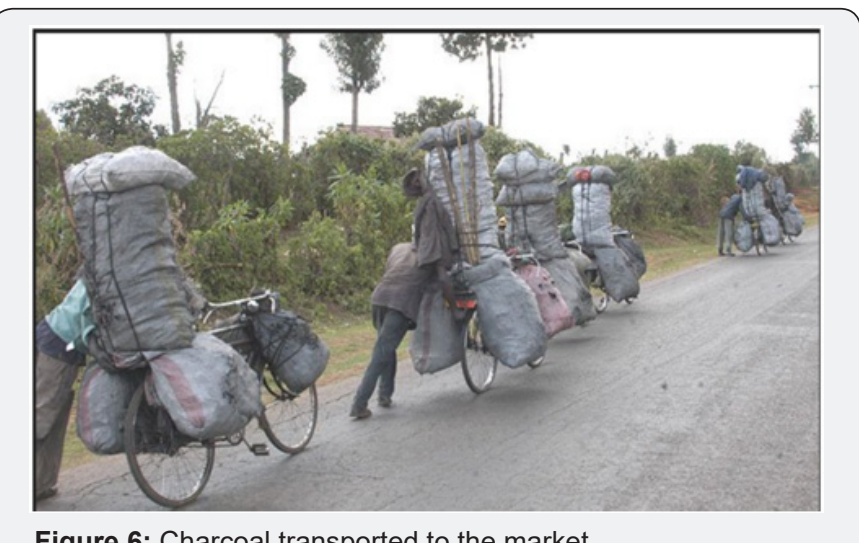

Figure 6: Charcoal transported to the market.

Considering the level of this destruction, precautions should be taken to save this very important water tower. Man as always known has unlimited wants and if given chance, will tend explore all resources within his reach. Following his unlimited wants, this forest will not remain safe. This source clearly how man compete for tree resources in the forest and rapidly degrades it. The wild animals whose habitats are here are engendered as was asserted [5]. They their nature, they will tend to migrate unfortunately they are also considered food and when seen, chances of them losing their lives are high. Strong voice should be found who speak firmly to help save the biodiversity supported by this forest.

\section{Settlements}

This paper established two reasons for people settling in Mau forest complex. Some claim they rightfully own land that they bought while others were settled by the government. The other group comprise the ones that encroach. Regardless of the category they fall, they both impact negatively on the forest. They have established structure of which some are grass thatched while other decently built as mansions. Home establishment starts with vegetation clearance. Their expansion still is characterized by loss of vegetation cover. The land-use change from forested or grassland to settlements consequently has an impact of driving away the wildlife that were formally occupying such places. They cab ne forced to move to un-safer places where they can be harmed or killed hence loss of biodiversity. Some crawling organisms may also be endangered. A part from the homesteads witnessed, there are shopping centres within the forest that also grow. The moving moror-bikes and even vehicles to these places make the wild life inhabiting these places feel unsafe. The people who have settled in the forest can be categorized to non-bush meat eaters or bush meat eaters. Some animals are poached and some killed for food. This scares away other animals and also reduces their numbers. Figures $7 \& 8$ is an indication of various structures that exist within Mau forest.

As evidence in the Figures $7 \& 8$ above, some of the animals that were tamed initially to help in hunting for food are seen. The only thing left on us is to sympathize with the animals that inhabitate the forest such as the antelope species. If they are not scared away, then they are caught and consumed by man. This paper advocates for the protection of both the land and the wildlife that are affected by the establishment of these structures. It known that trading centres normally develop into small urban centres which can grow to become cities. Development of these homesteads and trading centres have and will continue to degrade the forest as they draw other services and infrastructures like road network and even people hence they will expand at the expense of the forest.

\section{Agricultural Activities}

Food is the engine that drives and other organism's body. Agricultural activities support food production. As a result of authorized and unauthorized settlements in the Mau forest complex, agricultural activities have been seen to be undertaken with the forest. Sections of the forest have been cleared to pave way for agricultural activities for crop cultivation. Some of them include cash crops like tea as seen in Figures $7 \& 8$. 


\section{International Journal of Environmental Sciences \& Natural Resources}

Agricultural activities subject land to clearance of vegetation which leaves it bare and susceptible le to agents of erosion as has been mentioned earlier. This leads to loss of the top soil as it is swept by the run-off. Agricultural activities also loosen the soil and make it lose compactness. Some of the inorganic fertilizers applied to improve soil fertility also affect the soil micro-organisms which are meant for soil aeration. Excessive application of such fertilizers can also contribute to alteration of soil $\mathrm{pH}$. Where these fertilizes are swept by run-off to the water body may lead to eutrophication and also degrades water quality thereby affecting organisms. The directly and major impact of agriculture in Mau Forest complex in leaving the land bare through deforestation as evidenced in Figures $9 \& 10$.

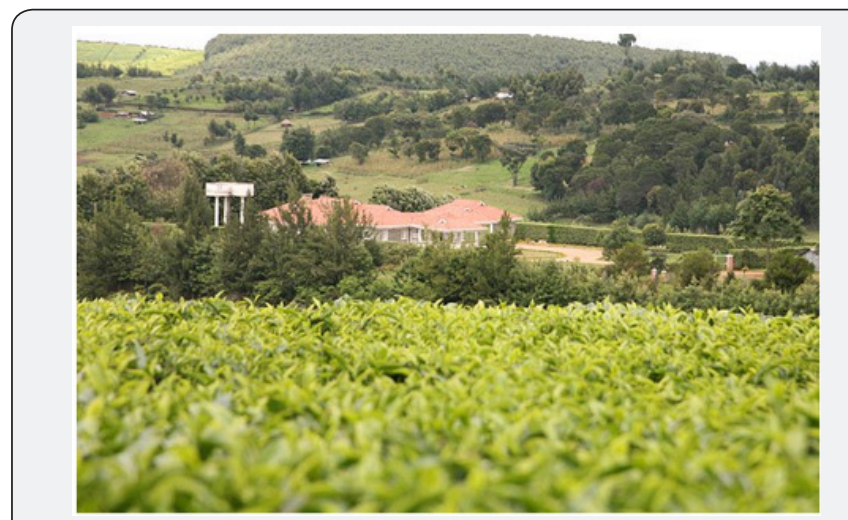

Figure 7: Homesteads in the forest.

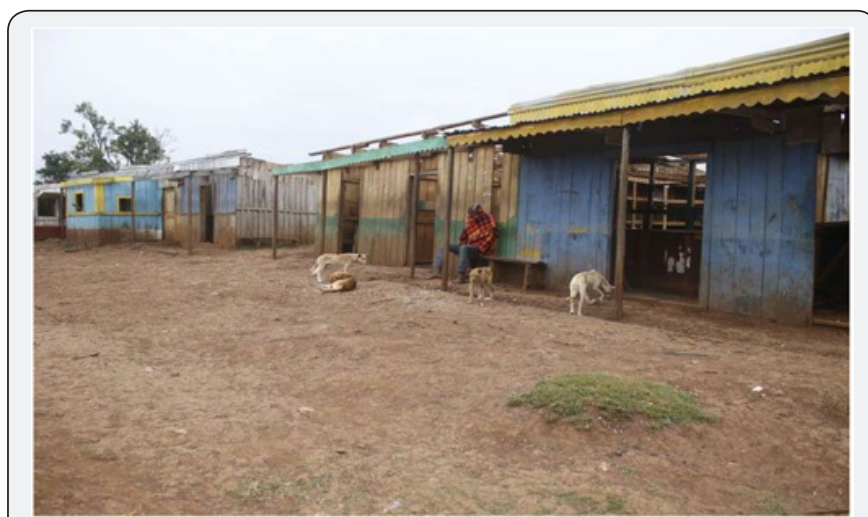

Figure 8: Kipchoge shopping centre in the forest.

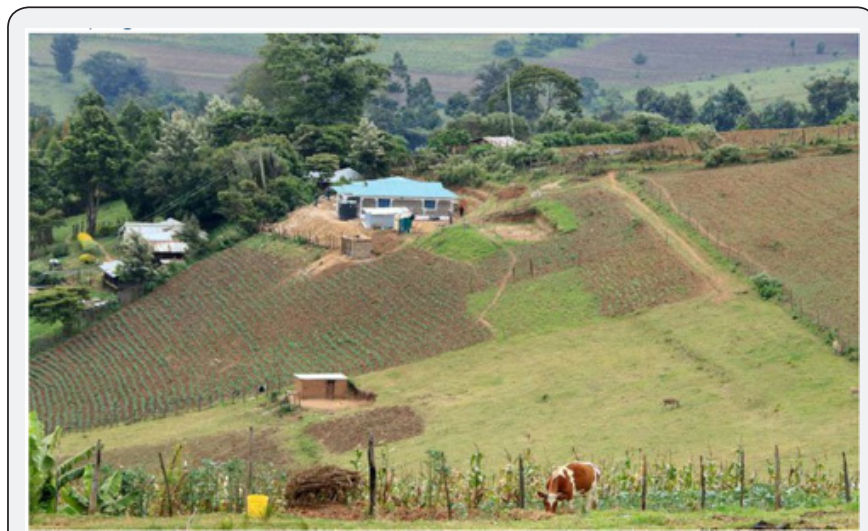

Figure 9: Homestead and agriculture.

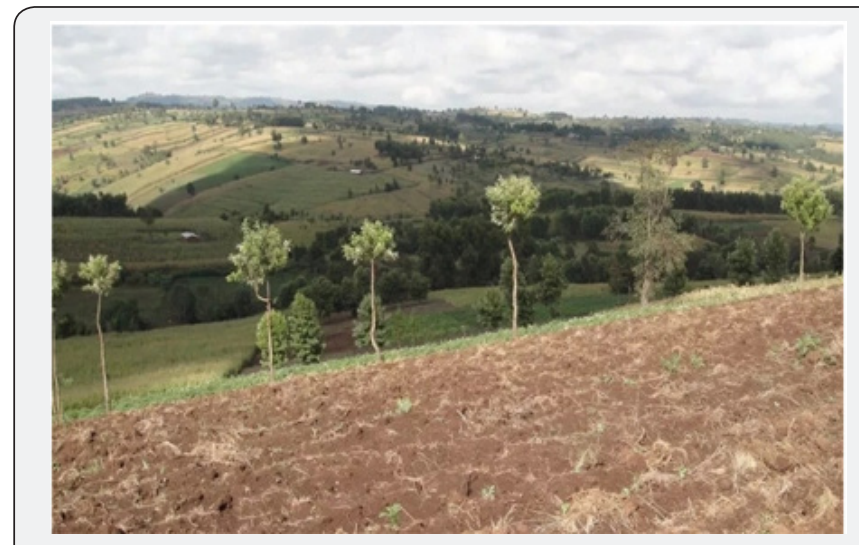

Figure 10: Agricultural activities.

It is clear that if stern actions are not taken then the forest will be turned into people's farms. The only this left is that the forest inhabitants to be enlightened to appreciate the forest. A lot can be seen to come from agriculture directly to support man's survival but it is high time we started appreciating the role of forests and accord the value and treatment they deserve. No one can eat food from agriculture enjoyably in a polluted environment. It is our environment that should be given priority for us to enjoy what we consume.

\section{Wild Fire}

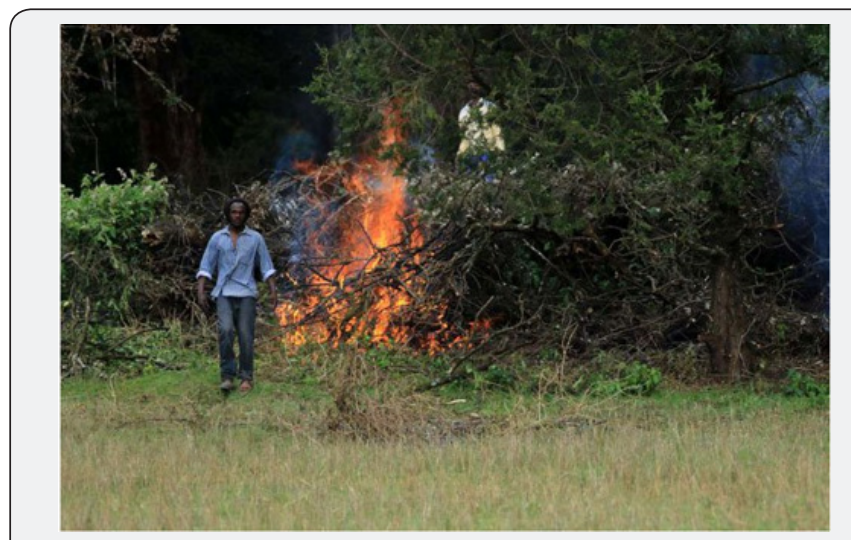

Figure 11: Section of Mau Forest (Sonki) on fire set by man on.

Mau Forest complex has suffered wild fire which has extensively consumed it land cover. It is sad to note that some these incidence are driven by man who may want to access some trees to be felled for timber production. Some sections of the forest that contain indigenous plants are thick and accessing them becomes problematic. The only option man takes it to set the forest on fire in order to access these resource. Fire can also be set in the forest to help drive away some dangerous wild animals like lions. The only challenge is that when the forest is set on fire, a lot of biodiversity is lost. Some species of plants cannot regenerate after being burnt hence loss of such genetic characteristics as was asserted [6]. Fire is not selective and therefore the intension of setting it has a lot of negative impacts on forest organisms. Crawling organisms are lost and 
due to thickness of some sections of the forest, fire consumes the vegetation making the incapable of regenerating. Self drives us to overlook the importance we get from forest. Figures 11 \& 12 shows the level of destruct by fire that Mau forest complex is subjected to by individual who want to fulfil their personal interest at the expense of other biodiversity. When man want to extend their settlement and farm lands they also set forest on fire. We need to change our attitude towards natural resources.

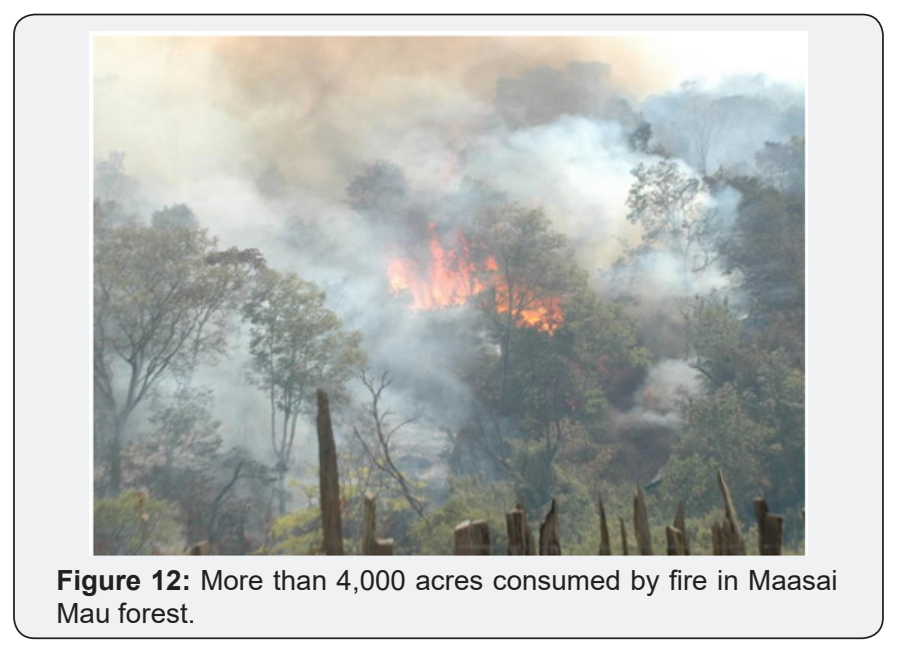

The Figure with the man is a photo that was taken on $27^{\text {th }}$ July 2018 by the Nation Media Group in Kenya. As is evidenced from the photo where the man has set the forest on fire, the place seems to be thick and accessing it is difficult. Some of these behaviour also comes with the perception that this is a government property and the locals because of eviction are now setting the forest on fire to punish the government. The consequences of our actions will just revolve around us. We are the people who will start walking kilometres while looking for water and at the same time impacted on directly because of pollution and contamination of the atmosphere. As I stated earlier, the benefits tied to natural resources are not directed to a given individual but all the locals, regions, states and globally people feel them. Mau forest is not an individual's property neither is it a government property and should not be treated as such. We as Kenyan citizens own it. We have seen the impacts of its degradation going trans-boundary. It is crucial to recognize that these forest are important for our lives on earth and we accord them the right treatment and honour.

\section{Effects of Man's Activities on Mau Forest}

Land-use and Land Cover Changes: There is clear indication from the forest that vegetation is being cleared at a faster rate. Illegal logging, charcoal burning, agricultural activities together with settlements established within the forest have impacted on the land cover loss as was posited [7]. These activities are characterized by clearance of vegetation that helps in controlling the rate of erosion, run-off speed and infiltration rates. Vegetation also enriches the soil with nutrients as they drop the dead leaves and these leaves are decomposed to provide human. This paper had mentioned earlier some of the significance attached to vegetation. Sections of the Mau Forest complex have been cleared and remained bare. This make it susceptible to agents of erosion like water and wind. Land-use changes have been witnessed in the forest as the areas initially covered with vegetation are being transformed into settlement, agricultural and trading centres where businesses take place. This compromises the roles performed by the vegetation and also degrades the environment in general based on the impacts associated with the human activities mentioned under this sections and other sections above such agricultural activities which make the soil to lose its compactness. An indication of this change is as shown in Figures 13 \& 14 .

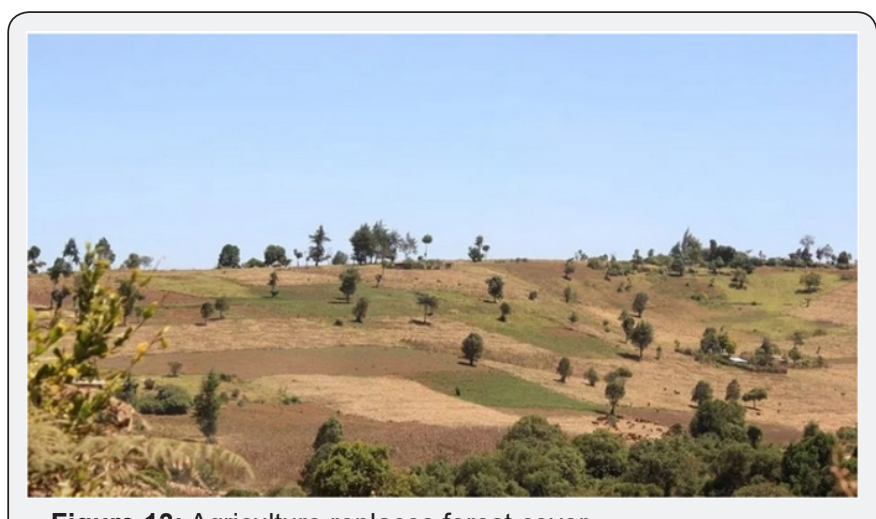

Figure 13: Agriculture replaces forest cover.

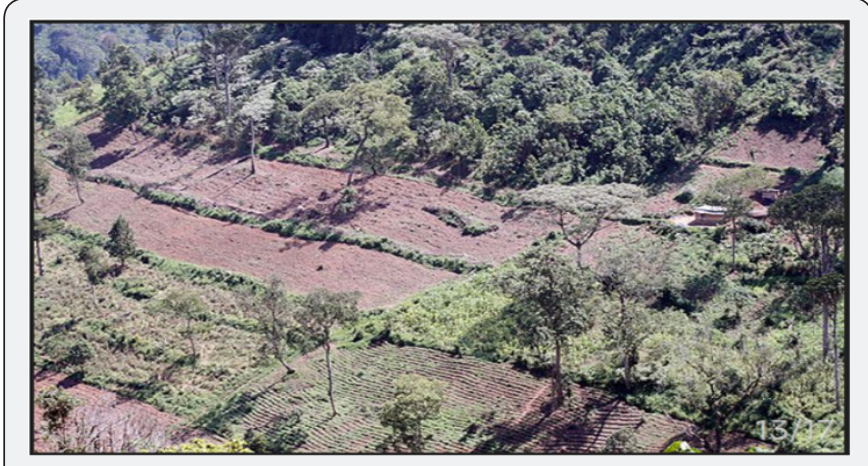

Figure 14: Homestead and agriculture inside forest.

Land cover is lost at a faster rate as people tend to acquire more land, clear it and put it under agricultural practices. The photo showing the homestead and agriculture portrays how extensive an individual can practice farming within the forest. This is a clear reflection and indication that the forest losses its cover at a faster rate since it is not only this individual captured but there are several others who practice agriculture in the forest.

Lower Water Volumes: This paper had mentioned earlier that vegetation helps in recharging atmospheric moisture through evapo-transpiration. Their degradation directly impact on the water cycle as was noted [8]. Vegetation also controls evaporation rate as they act as wind breakers. The moment vegetation is cleared, the area becomes prone to erosion which 
in turn leads to siltation of the water bodies. Degradation of Mau forest complex which has been witnessed has significantly affected the rivers and even lake that it supports. Some of the seasonal rivers and streams have been witnessed by the locals to be drying faster than they used to be. Mara River together with other rivers from Mau forest that feed Lake Nakuru with fresh water have also been affected and their water levels have gone down. Figures 15 \& 16 shows some rivers within Mau forest whose water levels have significantly gone down as a result of Mau forest degradation. Water bodies support aquatic biodiversity and the moment they are interfered with, you interfere with the very survival of the aquatic life as was established [9]. Human on the other hand are affected either at the catchment or downstream as water support a number of human activities. The volumes of Lake Nakuru has also been reported to go down as a result of Mau forest complex degradation in that the rivers that feed it with fresh water tend to dry up as a result of indecent human activities in Mau forest.

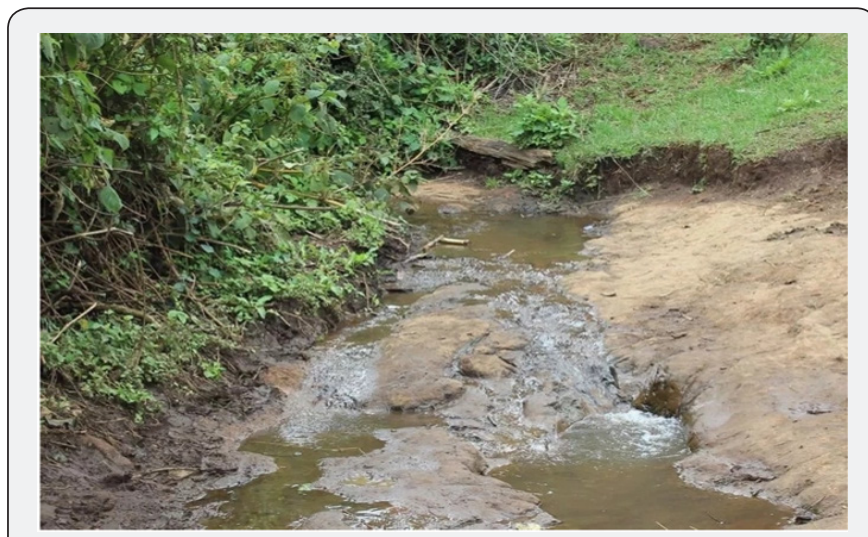

Figure 15: Section of Njoro River drying up.

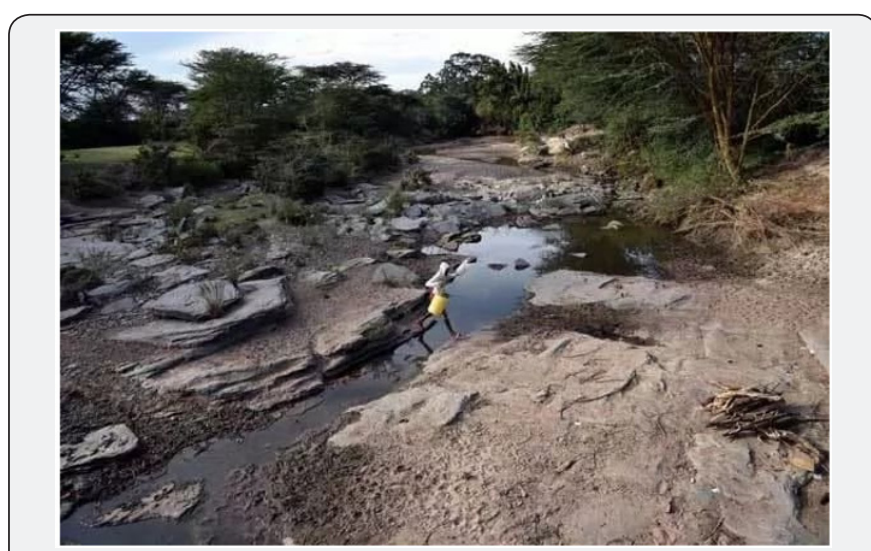

Figure 16: Reduced water levels in Mara River.

These are two different rivers supported by Mau forest complex. It is unfortunate that our lack of concern to the ecosystem can lead to this significant loss of biodiversity. As you can see from Figures $15 \& 16$ a river can be passed by just a stride. The aquatic lives are being lost are a result of forest degradation. Siltation has interfered with the depth of the river channels and they cannot hold the volumes they used to hold. It is imperative for us to realize that the aquatic biodiversity also have their right to live as one of the environmental principles of nature asserts that everything was created for a purpose. Co-existence between man and other organisms that nature provides is crucial. There are several rivers supported by Mau forest complex and they are all threatened by death as a result of this forest degradation.
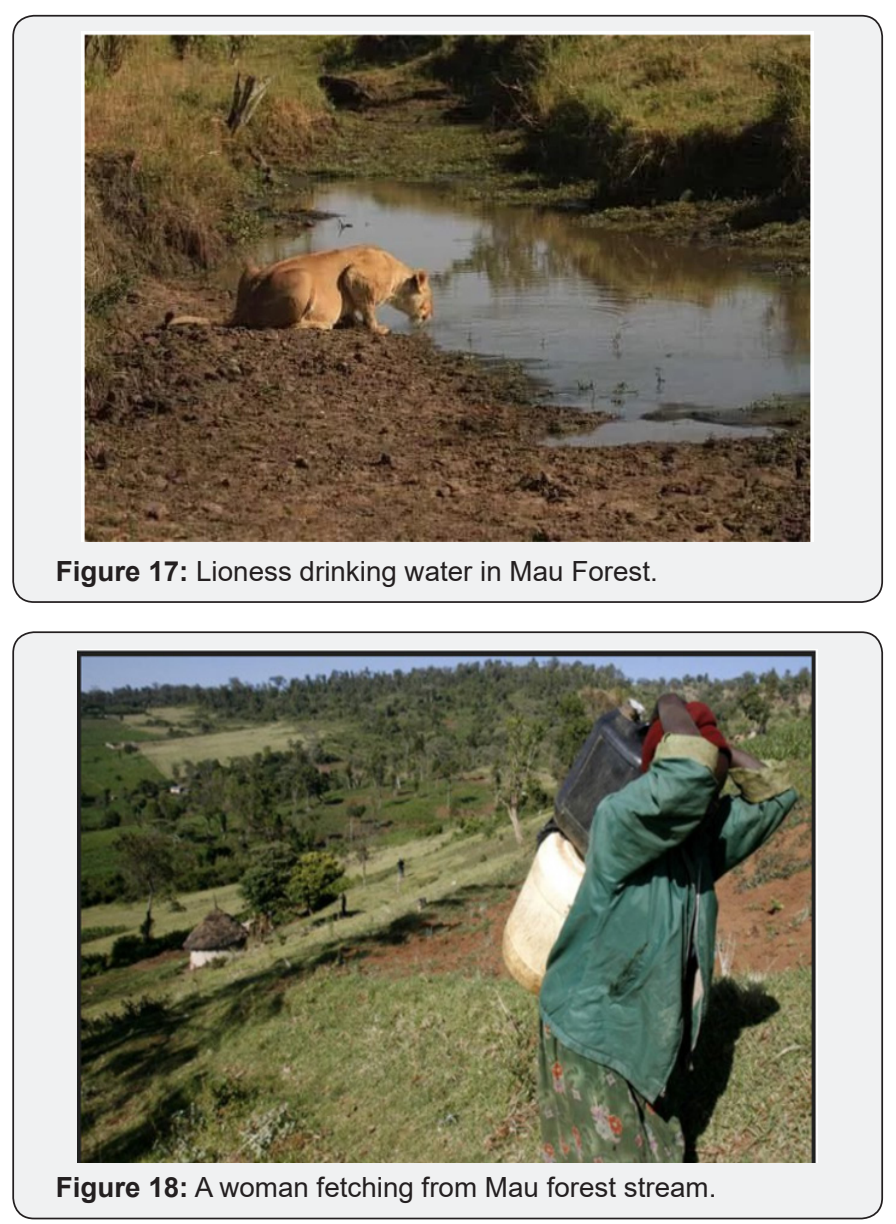

Impact on Wildlife: Mau Forest Complex support a number of wildlife species. There are lions, wild beasts, crocodiles, hippos among other forms of biodiversity. The forest provides refuge for various organisms that find shelter and live in it. It is therefore critical to protect and conserve and protect it for the benefit of these species of organisms since they contribute to the tourism sector in Kenya and other countries like Tanzania as was contended [10]. Unfortunately, man has considered himself as a superior organism and uses this as a privilege of denying other forms of life their right to exist. The destruction or degradation of the forest may be considered intentional following the way it is done. Those who live right inside Mau forest complex would be ones to lead in appreciation of nature. Ironically, they now compete in bringing forest down. The rivers affected by man's destruction of Mau forest as has been stated support a number of aquatic biodiversity. Their drying up is a direct indication of species extinction. Kenya as a country, benefits from the wildlife supported by Mau forest. The micro-climate created by the forest enables agricultural activities in the areas. It supports 
recreational activities and holds aesthetic value to the country. It is sad to notice that man's activities in the forest in now hindering the normal migration of wildbeasts into Maasai Mara and this will have direct impact on the tourism sector. Man together with other animals as was noted earlier cannot do without water. Figures 17 \& 18 shows how various organisms depend on water for survival.

We together with other animals need water to sustain our lives. The woman on the photo carries up to 30 litres on her back. The challenge is that we value ourselves too much and we cannot give credit to other life forms on how they help us. The local community in most cases have perceived it that it the government that benefits from the wildlife and therefore there is no need to engage themselves in protection them. The overall benefits we get from natural resource conservation is for the good of all citizens and not directed to specific individuals. Purified air is enjoyed by everyone. Let us kill self and we embrace the other forms of life for they were made to exist for our own good. Just to remind us of another environmental principle of nature which provides that nature is beautiful and we are the stewards of God's creations. Man should embrace other organisms as he was given dominion over all other creation as provided in the book of Genesis. If we scare and kill them is like a father disowning a child who has nowhere to go. We threaten them with extinction. Figure 19 shows how useful water is to the wildlife in Mau forest Complex.
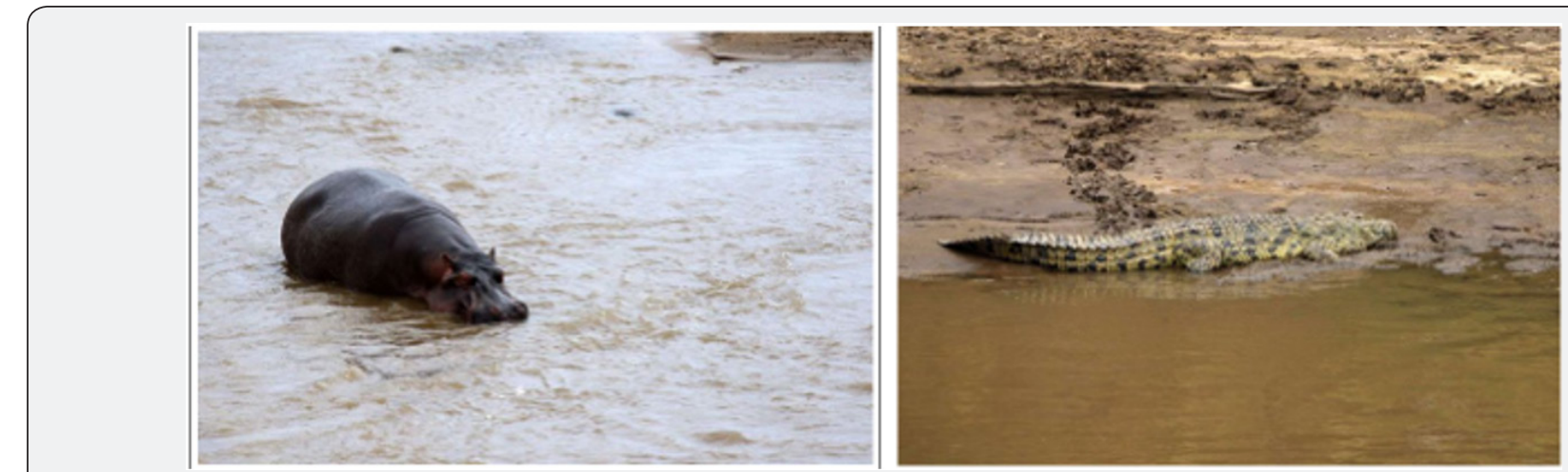

Figure 19: Hippo in Maasai Mara River 26/7/2018 and Crocodile in Maasai Mara River 31/7/2018.

Generally, Mau Forest Complex has suffered human degradation and if this does not stop the impact will be more significant as compared to the way it is currently. It has been noted that the forest cover has been reduced from 627,960 hectares to 253,000 hectares for the last 10 years. Figures 1 \& 2 shows the changes that have taken place between 1984 and 2018.

\section{A Comparison of Mau Forest Complex Coverage Between 1984 and 2018}

Significant changes have been evidenced in the forest. The year 2018 July is marked with several patches symbolizing the land that has lost its cover. Sections of the forest have been turned into agricultural lands, others cleared for charcoal burning while some sections have lost coverage because of illegal logging activities. The white patches indicate level of degradation that the forest experiences.

\section{Could Natural Resource Use be a Curse?}

Despite the benefits that accrue from the natural resources, the ones mentioned and others that this paper is silent about together with criticism of the people insisting that they own land in the protected area (Mau Forest Complex), we are left to sympathize with individuals affected by July 2018 evictions. As was stated earlier, people have lost their lives as they struggle over resources such as land. Some individuals have been displaced from their ancestral land when resources emerge like the Tullo Oil. The eviction of individuals from Mau Forest Complex has been characterized by property loss, injuries, homelessness and people suffering scorching sun during the day and cold at night. Figure 20 show some of the losses incurred during this eviction where a number of people we left homeless.
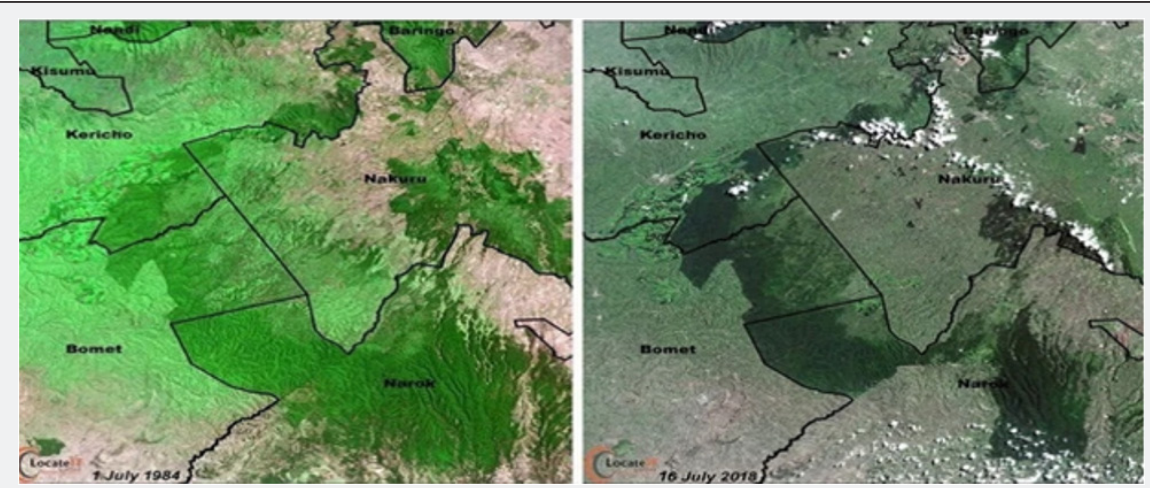

Figure 20: A comparison of Mau forest complex coverage between 1984 and 2018. 


\section{International Journal of Environmental Sciences \& Natural Resources}

The eviction of people from Mau forest Complex is a move that is appreciated by the conservationists like us but it has come with a lot of pain that make people view natural resource use as a curse. A lot of property have been lost people suffer hunger, cold and scorching sun with their kids. Emotions are expressed on the property lost including the trading centres that have been brought down. Figure 21 shows the burnt trading centre and the emotion expression.
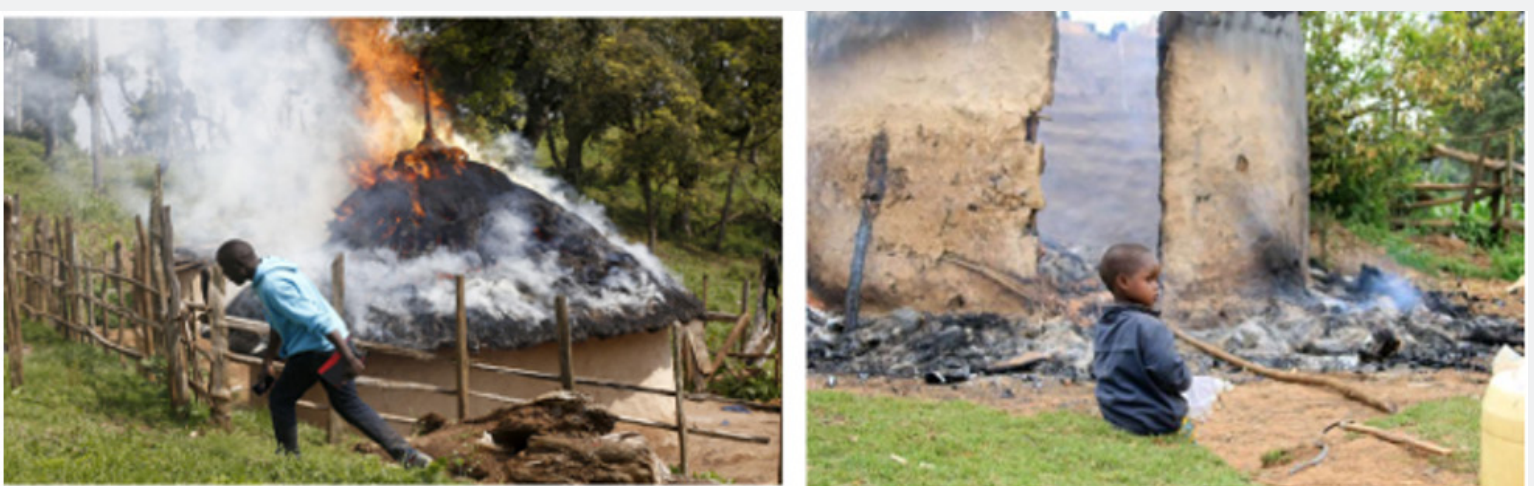

Figure 21: A house at Ororwet torched on 21/7/2018 and child left stranded after house torched at Kipchoge area.

People have felt the pain of moving out of the forest. They have lost livelihoods, 'their' fertile agricultural lands, closeness to the water sources, direct interaction with nature and fresh air purified by the forest. This is sad in deed but the question will still remain that can there be life without the natural resources such as water and forest and well managed land? If our answer is no, then the way forward is to swallow our pains and let's restore the degraded Mau Forest Complex for our good and for the good of the future generations.

\section{Conclusion}

This paper has noted that individuals who are overridden by self will never appreciate nature. It high time we knew that it's land that owns us but not us owning it as a resource. The benefits that accrue from natural resources cannot be overstated. It is imperative to join hands in appreciating our environment and accord it the honour it deserves. The movement towards a better future at times become bitter and is characterized with tears and a lot of obstacles met. When we remain strong and apply the right strategies we achieve much no matter how painful and difficult the strategies may appear. Let us embrace the natural resources and join hands in their proper management for they hold our lives now and in the future. I therefore recommend that this journey depicted in Figures 22 \& 23 to continue however painful it appears [11-14].
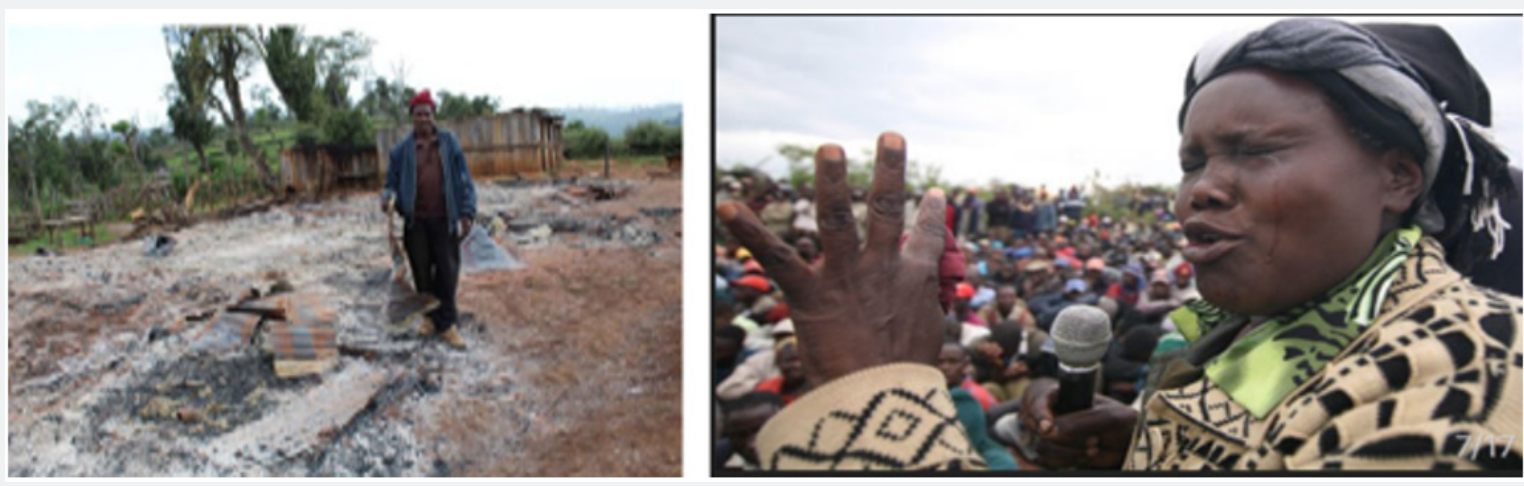

Figure 22: Burnt Kipchoge trading centre and their Emotions overwhelm the evictee.

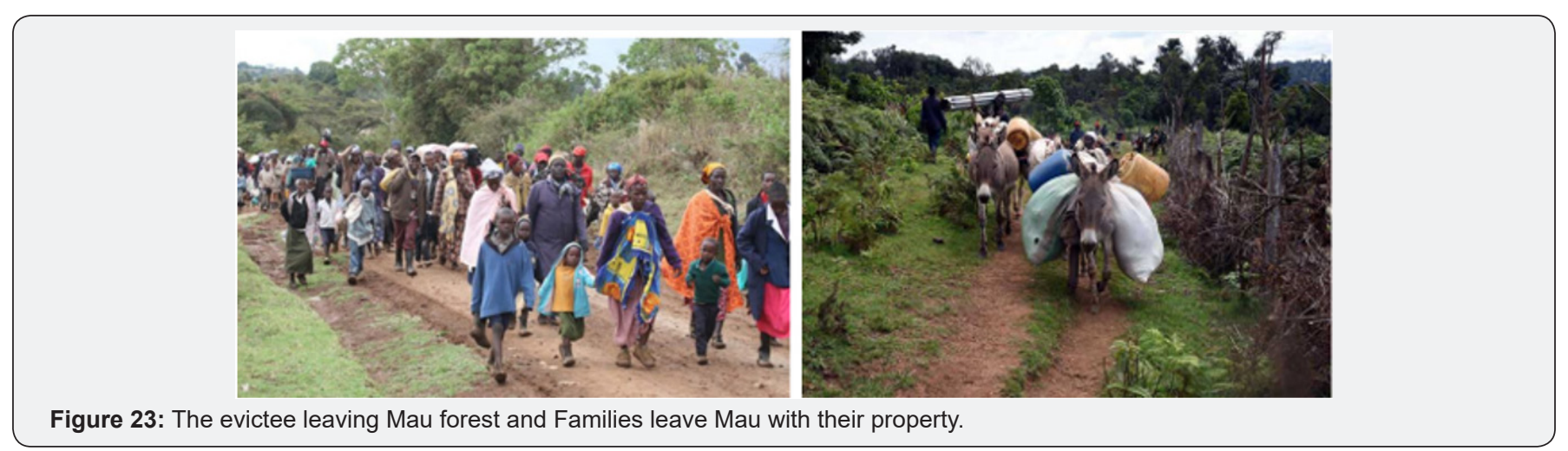


The movement shown by this Figures is not an easy one as it may appear but what it aims at achieving is the most important thing. I conclude by appealing to all members affected to swallow our sadness and sorrows and join hands in fighting for a better future by embracing and appreciating the natural resources for they hold our lives. Let us shun self and review our activities that negatively impact on the environment.

\section{References}

1. Ayuyo IO, Sweta L (2014) Land Cover and Land Use Mapping and Change Detection of Mau Complex in Kenya Using Geospatial Technology. International Journal of Science and Research (IJSR) 3(3).

2. Bewernick T (2016) Mapping Forest Degradation in the Mau Forest Complex Using NDFI Time Series. Laboratory of Geo-Information Science and Remote Sensing (minor MSc thesis report).

3. Boitt MK (2016) Impacts of Mau Forest Catchment on the Great Rift Valley Lakes in Kenya. Journal of Geoscience and Environment Protection 4: 137-145.

4. Klopp JM, Sang JK (2011) Maps Power and the Destruction of the Mau Forest in Kenya. Journal of Science \& Technology Winter/Spring 2011.

5. Ouko MC, Odhiambo AM, Boitt KM (2016) Assessment of Hydrological Impacts of Mau Forest, Kenya. Journal of Hydrology: Current Research $7(1)$.

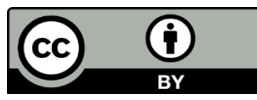

This work is licensed under Creative Commons Attribution 4.0 License

DOI: 10.19080/IJESNR.2018.14.555880
6. Swart R (2016) Monitoring 40 Years of Land use Change in the Mau Forest Complex, Kenya: A Land Use Change Driver Analysis. Master thesis report.

7. https://www.tuko.co.ke/281470-the-mau-forest-destructionpictures.html\#281470

8. http://www.mediamaxnetwork.co.ke/411662/locals-livestock-feelheat-mau-forest-destruction/

9. https://www.nation.co.ke/news/1056-633658-jn6s9ez/index.html

10. https://www.nation.co.ke/news/Charcoal-logging-wiping-out-Mauforest/1056-4329818-cprtig/index.html

11. https://www.nation.co.ke/lifestyle/dn2/Who-will-save-MauForest/957860-3831084-5xcgkxz/index.html

12. https://www.nation.co.ke/news/1056-686616-jk20wwz/index.html

13. http://www.mediamaxnetwork.co.ke/451580/8000-evicted-frommau-says-state/

14. http://www.awcfs.org/index.php/component/k2/item/1503mau-forest-destruction-is-a-threat-to-the-east-african-regionalintegration.

\section{Your next submission with Juniper Publishers} will reach you the below assets

- Quality Editorial service

- Swift Peer Review

- Reprints availability

- E-prints Service

- Manuscript Podcast for convenient understanding

- Global attainment for your research

- Manuscript accessibility in different formats

( Pdf, E-pub, Full Text, Audio)

- Unceasing customer service

Track the below URL for one-step submission https://juniperpublishers.com/online-submission.php 